\title{
Gambaran Risiko Terjadinya Gangguan Female Athlete Triad Syndrome pada Mahasiswi Olahraga
}

Ardi Setyo Nugroho ${ }^{a}$, Bambang Purwanto ${ }^{\text {b }}$

abUniversitas Airlangga, Indonesia

Correspondence: ardisetyo69@gmail.com

Received: 21 Jul 2020 Accepted: 18 Aug 2020 Published: 31 Oct 2020

\begin{abstract}
This study aims to describe how much the risk of the occurrence Female Athlete Triad (FAT) Syndrome in sports students. This research uses a quantitative approach with survey data collection techniques. The research respondents were 60 selected by quota sampling. The Instrument research use questionnaire that refers to the Female Athlete Triad: Cumulative Risk Assessment. The results showed the risk of impaired energy availability from a history of low frequency of eating $50 \%(\mathrm{n}=30)$, regulate body weight $41.7 \%(\mathrm{n}=25)$, specific lifestyle $40 \%(n=24)$, fasting habits $60 \%(n=36)$ and eating disorders $65 \%(n=39)$. The risk of menstrual disorders of menarche delayed was 25\% ( $\mathrm{n}=15)$, oligomenorrhea $50 \%(\mathrm{n}=30)$ and amenorrhea secondary $53.3 \%(\mathrm{n}=32)$. Risk of bone disorders $30 \%(\mathrm{n}=18)$. The description of the results of this study shows that the risk of sports college students suffering from FAT syndrome is quite large. The most surprising finding in this study was the low level of knowledge and information related to FAT syndrome among sports students. Given the large impact on health, necessary screening and further medical examinations as well as providing education about FAT syndrome disorders to female college students.
\end{abstract}

Keywords: female athlete; energy availability; menstruation; bone density

\section{Abstrak}

Penelitian ini bertujuan mengetahui gambaran seberapa besar risiko terjadinya sindroma Female Atblete Triad (FAT) pada mahasiswi olahraga. Penelitian ini menggunakan pendekatan kuantitatif dengan teknik pengumpulan data survei. Responden penelitian adalah mahasiswi berjumlah 60 orang yang dipilih dengan teknik quota sampling. Instrumen pengumpulan data menggunakan kuisioner terperinci yang mengacu pada Female Athlete Triad: Cumulative Risk Assessment. Hasil penelitian menunjukkan risiko gangguan ketersediaan energi dari riwayat rendahnya frekuensi makan 50\% ( $n=30)$, pengaturan berat badan $41,7 \%(n=25)$, gaya hidup spesifik 40\% ( $n=24)$, kebiasaan berpuasa $60 \%(n=36)$ dan gangguan makan $65 \%(n=39)$. Risiko gangguan menstruasi dari riwayat menarche tertunda 25\% ( $\mathrm{n}=15)$, oligomenorrhea $50 \%(\mathrm{n}=30)$ dan amenorrhea sekunder 53,3\% ( $\mathrm{n}=32)$. Risiko gangguan tulang 30\% ( $\mathrm{n}=18)$. Gambaran hasil penelitian ini menunjukkan risiko mahasiswi olahraga menderita sindroma FAT cukup besar. Temuan paling mengejutkan dalam penelitian ini adalah rendahnya pengetahuan dan informasi terkait sindroma FAT di kalangan mahasiswi olahraga. Mengingat dampak yang besar terhadap kesehatan, perlu dilakukan skrining dan pemeriksaan medis lebih lanjut serta pemberian edukasi tentang gangguan sindroma FAT kepada mahasiswi olahraga.

Kata kunci: atlet putri; ketersediaan energi; menstruasi; kepadatan tulang 


\section{Pendahuluan}

Kontribusi kaum perempuan dalam kemajuan olahraga di Indonesia tidak dapat dipandang remeh, dalam sejarah keolahragaan di Indonesia atlet putri memberikan bukti sumbangsihnya terhadap prestasi olahraga di tingkat dunia. Medali pertama Indonesia ajang Olimpiade Seoul ke-24 tahun 1988 dari cabor panahan diraih oleh tiga atlet putri yang mendapat julukan "Tiga Srikandi Indonesia" yaitu Nurfitriyana S. Lantang, Lilies Handayani dan Kusuma Wardhani (KEMENPORA RI, 2016b). Olimpiade selanjutnya pada tahun 1992 di Barcelona, salah satu medali emas pertama untuk indonesia juga disumbangkan oleh atlet putri dari cabor bulutangkis yaitu Susi Susanti yang saat ini menjadi legenda atlet bulutangkis putri Indonesia (KEMENPORA RI, 2012).

Perolehan medali Indonesia di ajang olahraga dunia, seringkali justru diawali oleh atlet putri. Medali pertama Indonesia di ajang Olimpiade tahun 2016 diraih oleh lifter (atlet angkat berat) putri Sri Wahyuni Agustini. Keberhasilan Sri Wahyuni Agustiani meraih medali perak yang menjadi perolehan medali pertama untuk Indonesia di Olimpiade Rio de Janeiro tahun 2016 menjadi motivasi atlet lain untuk memberikan performa maksimal (KEMENPORA RI, 2016a). Pada ajang multi-event Asian Games XVIII tahun 2018 perolehan medali indonesia dibuka dengan medali emas pertama dari cabor taekwondo di nomor individual poomsae putri oleh Defia Rosmaniar (KEMENPORA RI, 2018). Asian Games XVIII tahun 2018, Indonesia mengirimkan 416 atlet putri yang menyumbangkan 11 medali emas dari keseluruhan 31 medali emas yang diperoleh. Hal ini menunjukkan, kontribusi besar atlet putri dalam prestasi olahraga Indonesia di ajang internasional (Badriyah, 2019).

Prestasi yang diraih tentunya melewati proses pelatihan yang tidak sebentar dan seringkali terjadi gangguan kesehatan sebagai konsekuensinya. Pelatihan olahraga jangka panjang yang dilakukan secara intens dapat menimbulkan stres metabolik akut, intermiten sampai kronis, karena peningkatan pengeluaran energi dan asupan nutrisi yang tidak seimbang (Pauli \& Berga, 2010). Beban latihan yang tidak mampu dikompensasi fisiologis tubuh serta tekanan mental akibat kompetisi olahraga menyebabkan gangguan ketersediaan energi dan keseimbangan sistem endokrin, sehingga atlet putri berisiko besar mengalami sindroma Female Atblete Triad (FAT) (Matzkin, Curry, \& Whitlock, 2015). Atlet putri dari semua jenis cabang olahraga dan jenjang kompetisi berisiko sindroma FAT, tetapi resiko paling tinggi dimiliki atlet putri pada cabang olahraga predominasi daya tahan (endurance) (Tosi, Maslyanskaya, Dodson, \& Coupey, 2019). Female Athlete Triad (FAT) adalah sindroma yang ditandai oleh gangguan dari tiga komponen yaitu: ketersediaan energi, fungsi menstruasi, dan kepadatan tulang (Aurelia Nattiv et al., 2007).

Sindrom FAT pertama kali dikemukakan oleh American College of Sports Medicine (ACSM) pada tahun 1992 setelah banyak ahli mengamati pasien atlet putri pada rentang usia remaja dan dewasa (A Nattiv, Agostini, Drinkwater, \& Yeager, 1994). Prevalensi sindroma FAT pada atlet putri di seluruh dunia mencapai 40-50\% (Sherwood, 2016). Prevalensi di sekolah menengah dan perguruan tinggi di Amerika, 78\% pelajar atlet dan 65\% pelajar non-atlet ditemukan menderita sindroma FAT (Hoch et al., 2009). Hasil Riset Kesehatan Dasar melaporkan terdapat 13,7\% perempuan usia subur yang mengalami gangguan menstruasi (RISKESDAS, 2013). Sekitar 50\% perempuan yang berolahraga secara teratur mengalami gangguan menstruasi yang halus dan sekitar $30 \%$ perempuan mengalami amenorrhea (M. J. De Souza et al., 2010).

Data prevalensi penderita FAT di Indonesia secara nasional belum ada hingga saat ini. Sebetulnya, keberadaan data prevalensi penderita sindroma FAT dari kalangan atlet maupun penggiat olahraga yang bersifat rekreasional penting untuk diketahui. Data tersebut dapat digunakan sebagai gambaran di lapangan untuk melakukan langkah promotif dan preventif terhadap sindroma FAT, mengingat dampak besar di masa depan bagi penderita sindroma FAT. Bukan hanya dampak negatif pada 
penurunan prestasi, tetapi dampak kesehatan di masa depan yang terancam. Diagnosis penderita sindroma FAT hanya perlu menunjukkan satu atau dua keadaan dari tiga komponen ketersediaan energi yang rendah, gangguan menstruasi atau gangguan kepadatan tulang (Matzkin, Curry \& Whitlock, 2015). Sehingga deteksi dini terhadap sindroma FAT ini dapat dilakukan melalui riwayat individu yang berkaitan dengan risiko gangguan dari tiga komponen tersebut.

Survei berdasarkan pada penilaian risiko kumulatif sindroma FAT dari The 2014 Female Athlete Triad Coalition Consensus Statement perlu dilakukan untuk mengetahui perkiraan data dari prevalensi penderita sindroma FAT di Indonesia khususnya pada kalangan mahasiswi di perguruan tinggi yang menempuh pendidikan di jurusan olahraga. Gambaran yang di dapat dari mahasiswi jurusan olahraga dianggap dapat menggambarkan kalangan atlet maupun individu yang aktif berolahraga secara rekreasional.

\section{Metode Penelitian}

Penelitian ini menggunakan pendekatan kuantitatif dengan teknik pengumpulan data tes survei. Responden penelitian adalah mahasiswi aktif angkatan tahun 2014-2020 Fakultas Ilmu Keolahragaan Universitas Negeri Semarang berjumlah 60 orang. Responden penelitian ditentukan dengan teknik quota sampling. Instrumen pengumpulan data menggunakan kuisioner terperinci mencakup pertanyaan terkait segala aktivitas dan riwayat yang menjadi risiko sindroma FAT. Pertanyaan yang diajukan mengacu pada Female Atblete Triad: Cumulative Risk. Assessment yang dikembangkan untuk memperoleh informasi yang lebih mendalam (De Souza et al., 2014).

\section{Tabel 1. Triad Consensus Panel Screening Questions}

\section{Pertanyaan Skrining Female Athlete Triad Syndrome}

1. Pernahkah Anda mengalami menstruasi? Have you ever had a menstrual period?

2. Berapa usia Anda ketika Anda memiliki periode menstruasi pertama Anda? How old were you when you had your first menstrual period?

3. Kapan periode menstruasi terakhir Anda? When was your most recent menstrual period?

4. Berapa banyak periode yang Anda miliki dalam 12 bulan terakhir? How many periods have you had in the past 12 months?

5. Apakah Anda saat ini mengonsumsi hormon perempuan (estrogen, progesteron atau pil KB)? Are you presently taking any female hormones (estrogen, progesterone, birth control pills)?

6. Apakah Anda khawatir dengan berat badan Anda? Do you worry about your weight?

7. Apakah Anda mencoba atau ada orang yang merekomendasikan Anda menambah atau mengurangi berat badan? Are you trying to or has anyone recommended that you gain or lose weight?

8. Apakah Anda melakukan diet khusus atau menghindari jenis makanan tertentu atau kelompok makanan?

Are you on a special diet or do you avoid certain types of foods or food groups?

9. Pernahkah Anda mengalami gangguan makan?

Have you ever had an eating disorder? 


\section{Pertanyaan Skrining Female Athlete Triad Syndrome}

10. Pernahkah Anda mengalami fraktur stres?

Have you ever had a stress fracture?

11. Pernahkah Anda diberitahu memiliki kepadatan tulang yang rendah (osteopenia atau osteoporosis)?

Have you ever been told you have low bone density (osteopenia or osteoporosis)?

Female Atblete Triad: Cumulative Risk Assessment (De Souza et al., 2014).

Data penelitian ini di analisis dan disajikan menggunakan metode deskriptif persentase, metode analisis deskriptif persentase digunakan untuk menggambarkan masing-masing variabel agar lebih mudah dalam memahaminya. Data yang diperoleh selanjutnya dikumpulkan, ditabulasi dan ditampilkan menggunakan ukuran pemusatan data secara numerik statistik dan deskriptif untuk mengetahui hasil penelitian.

\section{Hasil}

Aktivitas fisik dalam dan luar perkuliahan

Tabel 2. Profil dan Aktivitas Responden Penelitian

\begin{tabular}{|c|c|c|c|}
\hline Profil & Klasifikasi & Jumlah responden (orang) & Persentase (\%) \\
\hline \multirow[t]{3}{*}{ Jurusan } & IKOR & 27 & 45 \\
\hline & PJKR & 16 & 26,7 \\
\hline & PKO & 17 & 28,3 \\
\hline \multicolumn{2}{|c|}{ Total Partisipan } & 60 & 100 \\
\hline Aktivitas olahraga (selain & Atlet & 20 & 33,3 \\
\hline perkuliahan). & Rekreasional & 40 & 66,7 \\
\hline \multicolumn{2}{|c|}{ Total Partisipan } & 60 & 100 \\
\hline \multirow{3}{*}{$\begin{array}{l}\text { Frekuensi mata kuliah } \\
\text { praktik. }\end{array}$} & $<3 \mathrm{kali} /$ minggu & 27 & 45 \\
\hline & $<5 \mathrm{kali} / \mathrm{minggu}$ & 26 & 43,3 \\
\hline & $>5 \mathrm{kali} / \mathrm{minggu}$ & 7 & 11,7 \\
\hline \multicolumn{2}{|c|}{ Total Partisipan } & 60 & 100 \\
\hline \multirow{5}{*}{$\begin{array}{l}\text { Frekuensi Latihan diluar } \\
\text { perkuliahan }\end{array}$} & $<3 \mathrm{kali} /$ minggu & 10 & 16,6 \\
\hline & $3 \mathrm{kali} /$ minggu & 25 & 41,7 \\
\hline & $4 \mathrm{kali} /$ minggu & 7 & 11,7 \\
\hline & $5 \mathrm{kali} / \mathrm{minggu}$ & 9 & 15 \\
\hline & $>5 \mathrm{kali} / \mathrm{minggu}$ & 9 & 15 \\
\hline \multicolumn{2}{|c|}{ Total Partisipan } & 60 & 100 \\
\hline Durasi dalam satu sesi & $<$ dari 1 jam & 0 & 0 \\
\hline \multirow{3}{*}{ latihan } & 1 jam & 7 & 11,7 \\
\hline & $2 \mathrm{jam}$ & 32 & 53,3 \\
\hline & $>$ dari 2 jam & 21 & 35 \\
\hline \multicolumn{2}{|c|}{ Total Partisipan } & 60 & 100 \\
\hline \multirow{4}{*}{$\begin{array}{l}\text { Jenjang kompetisi yang } \\
\text { telah diikuti }\end{array}$} & Kabupaten & 16 & 26,7 \\
\hline & Provinsi & 23 & 38,3 \\
\hline & Nasional & 18 & 30 \\
\hline & Internasional & 3 & 5 \\
\hline \multicolumn{2}{|c|}{ Total Partisipan } & 60 & 100 \\
\hline
\end{tabular}

Responden penelitian ini berasal dari populasi mahasiswi Fakultas Ilmu Keolahragaan Universitas Negeri Semarang dengan sebaran data: jurusan Ilmu Keolahragaan (IKOR) 45\% ( $n=27)$, jurusan Pendidikan Jasmani Kesehatan dan Rekreasi (PJKR) 26,7\% ( $\mathrm{n}=16)$ dan jurusan Pendidikan 
Kepelatihan Olahraga (PKO) 28,3\% ( $\mathrm{n}=17)$. Hasil penelitian ini responden atlet aktif sebanyak $33,3 \%(n=20)$ dan aktif berolahraga atau rekreasional sebanyak $66,7 \%(n=60)$. Kedua kalangan ini dianggap dapat mewakili populasi yang lebih luas dalam masyarakat. Kedua kalangan ini dapat mewakili populasi yang aktif berolahraga.

Hasil penelitian terkait frekuensi aktivitas perkuliahan dan latihan rutin dari responden, untuk aktivitas perkuliahan praktik olahraga kurang dari $3 \mathrm{kali} /$ minggu $45 \%(\mathrm{n}=27)$, kurang dari 5 $\mathrm{kali} /$ minggu 43,3\% $(\mathrm{n}=26)$ dan lebih dari $5 \mathrm{kali} /$ minggu 11,7\% $(\mathrm{n}=7)$. Sedangkan, aktivitas latihan di luar perkuliahan dengan frekuensi kurang dari 3 kali/minggu 16,6\% $(n=10), 41,7 \%(n=25)$ memiliki frekuensi latihan $3 \mathrm{kali} /$ minggu, frekuensi 4 kali/minggu 11,7 $(\mathrm{n}=7)$ dan frekuensi 5 atau lebih dari 5 kali/minggu sama-sama sebanyak 15\% $(\mathrm{n}=9)$. Durasi latihan yang dilakukan responden setiap satu sesi latihan adalah 1-2 jam/sesi dengan mayoritas 53,3\% $(n=32)$ menghabiskan waktu 2 jam setiap latihan, $11,7 \%(n=7)$ responden lebih sedikit waktu yang perlukan untuk setiap latihan yaitu 1 jam dan 35\% ( $\mathrm{n}=21)$ responden menghabiskan kan waktu lebih dari 2 jam setiap latihan. Jenjang kompetisi tertinggi yang pernah diikuti responden yaitu: kabupaten $26,7 \%(\mathrm{n}=16)$, provinsi $38,3 \%$ $(n=23)$, nasional 30\% ( $n=18)$ dan internasional 5\% $(n=3)$.

Hasil penelitian menunjukkan tingkat aktivitas yang tinggi dan intensif dalam perkuliahan dan latihan rutin yang dilakukan oleh responden. Aktivitas perkuliahan praktik olahraga dilakukan lebih dari tiga kali selama seminggu. Sedangkan, aktivitas latihan di luar perkuliahan juga menunjukan tingkat frekuensi yang sama. Durasi latihan yang dilakukan responden mayoritas menghabiskan waktu 2 jam setiap latihan.

\section{Ketersediaan Energi}

Tabel 3. Tanggapan Responden Tentang Ketersediaan Energi

\begin{tabular}{|c|c|c|c|}
\hline $\begin{array}{c}\text { Pertanyaan } \\
\text { Respon tentang ketersediaan energi }\end{array}$ & Tanggapan & $\begin{array}{l}\text { Jumlah responden } \\
\text { (orang) }\end{array}$ & Persentase $(\%)$ \\
\hline \multirow{4}{*}{ Frekuensi makan dalam sehari } & 1 kali/sehari & 1 & 1,7 \\
\hline & 2 kali/sehari & 30 & 50 \\
\hline & $3 \mathrm{kali} / \mathrm{sehari}$ & 28 & 46,6 \\
\hline & $>3 \mathrm{kali} / \mathrm{seh}$ ari & 1 & 1,7 \\
\hline \multicolumn{2}{|l|}{ Total Partisipan } & 60 & 100 \\
\hline \multirow[t]{2}{*}{ Pengaturan berat badan dari cabor } & $\mathrm{Ya}$ & 25 & 41,7 \\
\hline & Tidak & 35 & 58,3 \\
\hline \multicolumn{2}{|l|}{ Total Partisipan } & 60 & 100 \\
\hline \multirow{3}{*}{$\begin{array}{l}\text { Melakukan diet atau membatasi asupan } \\
\text { kalori }\end{array}$} & $\mathrm{Ya}$ & 15 & 25 \\
\hline & Tidak & 35 & 58,3 \\
\hline & Mungkin & 10 & 16,7 \\
\hline \multicolumn{2}{|l|}{ Total Partisipan } & 60 & 100 \\
\hline \multirow{2}{*}{$\begin{array}{l}\text { Membatasi asupan makro nutrisi atau jenis } \\
\text { makanan tertentu }\end{array}$} & $\mathrm{Ya}$ & 24 & 40 \\
\hline & Tidak & 36 & 60 \\
\hline \multicolumn{2}{|l|}{ Total Partisipan } & 60 & 100 \\
\hline \multirow[t]{2}{*}{ Memiliki kebiasaan berpuasa } & Ya & 36 & 60 \\
\hline & Tidak & 24 & 40 \\
\hline \multicolumn{2}{|l|}{ Total Partisipan } & 60 & 100 \\
\hline \multirow[t]{3}{*}{ Mengalami gangguan nafsu makan } & Tidak & 15 & 25 \\
\hline & Pernah & 39 & 65 \\
\hline & Sering & 6 & 10 \\
\hline \multicolumn{2}{|l|}{ Total Partisipan } & 60 & 100 \\
\hline \multirow{2}{*}{$\begin{array}{l}\text { Gangguan terjadi selama perkuliahan, } \\
\text { pelatihan atau kompetisi olahraga yang }\end{array}$} & $\mathrm{Ya}$ & 17 & 28,3 \\
\hline & Tidak & 27 & 45 \\
\hline
\end{tabular}


Ardi Setyo Nugroho, Bambang Purwanto

Gambaran Risiko Terjadinya Gangguan Female Athlete Triad Syndrome pada Mahasiswi Olahraga

\begin{tabular}{rccc}
\hline $\begin{array}{c}\text { Pertanyaan } \\
\text { Respon tentang ketersediaan energi }\end{array}$ & Tanggapan & $\begin{array}{c}\text { Jumlah responden } \\
\text { (orang) }\end{array}$ & Persentase (\%) \\
\hline intens & Mungkin & 16 & 26,7 \\
\hline Total Partisipan & & $\mathbf{6 0}$ & $\mathbf{1 0 0}$ \\
\hline
\end{tabular}

Hasil penelitian terkait ketersediaan energi pada frekuensi makan dalam sehari $50 \% \quad(n=30)$ responden biasa makan hanya 2 kali/sehari dan 46,6\% ( $n=28)$ responden memiliki frekuensi makan pada umumnya yaitu $3 \mathrm{kali} / \mathrm{sehari}$, selain itu sebanyak $1,7 \%(\mathrm{n}=1)$ responden memiliki kebiasaan makan 1 kali/sehari dan lebih dari 3 kali/sehari. Berdasarkan hasil penelitian 41,7 $(n=25)$ merupakan atlet dari cabor dengan tuntutan pengaturan berat badan, sebanyak 25\% $(n=15)$ responden melakukan diet membatasi asupan kalori harian dan 16,7\% $(n=10)$ mungkin juga membatasi asupan kalori hariannya tanpa disengaja atau pun disadari. Responden yang melaporkan berpantangan dengan makanan tertentu atau membatasi asupan makro nutrisi seperti karbohidrat, lemak dan protein sebanyak 40\% (24 orang). Selain itu, 60\% ( $n=36)$ dari responden memiliki kebiasaan berpuasa pada hari-hari tertentu.

Hasil penelitian terkait ketersediaan energi pada frekuensi makan menunjukkan bahwa responden biasa makan hanya 2 kali/sehari. Berdasarkan hasil penelitian juga menunjukkan kebiasaan pembatasan kalori yang dilakukan responden karena tuntutan cabor maupun kebiasaan yang telah dilakukan sebelumnya. Namun, mayoritas responden menyatakan kebiasaan tersebut tidak berkaitan dengan aktivitas yang dilakukan sehari-hari.

\section{Fungsi Menstruasi}

Tabel 4. Tanggapan Responden Tentang Fungsi Menstruasi

\begin{tabular}{|c|c|c|c|}
\hline Pertanyaan & Tanggapan & $\begin{array}{l}\text { Jumlah responden } \\
\text { (orang) }\end{array}$ & Persentase (\%) \\
\hline \multirow[t]{2}{*}{ Mengalami menstruasi } & $\mathrm{Ya}$ & 60 & 100 \\
\hline & Tidak & 0 & 0 \\
\hline \multicolumn{2}{|l|}{ Total Partisipan } & 60 & 100 \\
\hline \multirow[t]{2}{*}{ Konsumsi Pil kb atau terapi hormon } & $\mathrm{Ya}$ & 0 & 0 \\
\hline & Tidak & 60 & 100 \\
\hline \multicolumn{2}{|l|}{ Total Partisipan } & 60 & 100 \\
\hline \multirow[t]{2}{*}{ Usia saat menstruasi pertama } & 10-13 tahun & 45 & 75 \\
\hline & 14-16 tahun & 15 & 25 \\
\hline \multicolumn{2}{|l|}{ Total Partisipan } & 60 & 100 \\
\hline \multirow[t]{5}{*}{ Periode siklus menstruasi } & $<27$ hari & 10 & 16,7 \\
\hline & $>27$ hari & 23 & 38,3 \\
\hline & $<30$ hari & 17 & 28,3 \\
\hline & $<35$ hari & 7 & 11,7 \\
\hline & $>35$ hari & 3 & 5 \\
\hline \multicolumn{2}{|l|}{ Total Partisipan } & 60 & 100 \\
\hline \multirow{3}{*}{$\begin{array}{l}\text { Selama anda mengalami menstruasi, apakah } \\
\text { pernah menstruasi tertunda lebih dari } 35 \\
\text { hari? }\end{array}$} & Tidak & 26 & 43,3 \\
\hline & Pernah & 30 & 50 \\
\hline & Sering & 4 & 6,7 \\
\hline \multicolumn{2}{|l|}{ Total Partisipan } & 60 & 100 \\
\hline \multirow[t]{4}{*}{ Apakah gangguan tersebut berturut turut? } & Tidak & 55 & 91,6 \\
\hline & 2 kali & 1 & 1,7 \\
\hline & 3 kali & 1 & 1,7 \\
\hline & $>3$ kali & 3 & 5 \\
\hline \multicolumn{2}{|l|}{ Total Partisipan } & 60 & 100 \\
\hline Selama anda menstruasi, apakah pernah & Tidak & 27 & 45 \\
\hline
\end{tabular}


Ardi Setyo Nugroho, Bambang Purwanto

Gambaran Risiko Terjadinya Gangguan Female Athlete Triad Syndrome pada Mahasiswi Olahraga

\begin{tabular}{rlcc}
\hline \multicolumn{1}{c}{ Pertanyaan } & Tanggapan & $\begin{array}{c}\text { Jumlah responden } \\
\text { (orang) }\end{array}$ & Persentase (\%) \\
\hline $\begin{array}{r}\text { anda kehilangan satu periode penuh } \\
\text { menstruasi? }\end{array}$ & Pernah & 32 & 53,3 \\
\hline Total Partisipan & Sering & 1 & 1,7 \\
\hline Apakah gangguan tersebut berturut turut? & Tidak & $\mathbf{6 0}$ & $\mathbf{1 0 0}$ \\
& $2 \mathrm{kali}$ & 53 & 88,3 \\
& $3 \mathrm{kali}$ & 3 & 5 \\
& $>3 \mathrm{kali}$ & 1 & 1,7 \\
\hline Total Partisipan & & 3 & 5 \\
\hline & & $\mathbf{6 0}$ & $\mathbf{1 0 0}$ \\
\hline & Ya & & \\
Apakah gangguan tersebut terjadi selama & Tidak & 9 & 15 \\
perkuliahan, pelatihan atau kompetisi & Mungkin & 40 & 66,7 \\
olahraga yang intens? & Total Partisipan & 11 & 18,3 \\
\hline
\end{tabular}

Hasil penelitian menunjukkan sebanyak $95 \%(n=55)$ responden dalam penelitian ini memiliki siklus menstruasi normal yaitu antara 21-35 hari. Usia menarche rata-rata dari responden $75 \%(n=45)$ terjadi di usia 10-13 tahun dan 25\% $(\mathrm{n}=15)$ di usia 14-16 tahun. Berdasarkan hasil penelitian ini, sebanyak 25\% responden yang mengalami menarche di usia $14-16$ tahun. Sebanyak 53,3\% ( $n=32)$ responden pernah kehilangan satu periode penuh dari siklus menstruasi biasanya. Sebanyak 5\% $(n=3)$ responden juga melaporkan memiliki siklus menstruasi $>35$ hari dan $50 \%(n=30)$ responden pernah mengalami penundaan menstruasi selama lebih dari 35 hari, bahkan $6,7 \%(\mathrm{n}=4)$ sering mengalami penundaan tersebut.

Hasil penelitian menunjukkan mayoritas responden memiliki siklus menstruasi normal yaitu antara 21-35 hari. Usia menarche responden dimulai pada 10-16 tahun. Setengah dari total responden pernah kehilangan satu periode penuh dari siklus menstruasi biasanya. Gangguan menstruasi lainnya juga nampak terjadi pada responden. Namun, mayoritas responden menyatakan gangguan tersebut tidak berkaitan dengan aktivitas yang dilakukan sehari-hari.

\section{Kepadatan Tulang}

Tabel 5. Tanggapan Responden Tentang Kepadatan Tulang

\begin{tabular}{|c|c|c|c|}
\hline Pertanyaan & Tanggapan & $\begin{array}{l}\text { Jumlah responden } \\
\text { (orang) }\end{array}$ & Persentase (\%) \\
\hline \multirow[t]{3}{*}{ Apakah anda pernah mengalami cedera? } & Tidak & 13 & 21,7 \\
\hline & Pernah & 43 & 71,7 \\
\hline & Sering & 4 & 6,6 \\
\hline \multicolumn{2}{|l|}{ Total Partisipan } & 60 & 100 \\
\hline Apakah anda pernah mengalami gangguan & $\mathrm{Ya}$ & 18 & 30 \\
\hline tulang (kepadatan rendah, retak/patah)? & Tidak & 42 & 70 \\
\hline \multicolumn{2}{|l|}{ Total Partisipan } & 60 & 100 \\
\hline \multirow[t]{3}{*}{ Berapa kali gangguan tersebut terjadi? } & Tidak pernah & 42 & 70 \\
\hline & $1 \mathrm{kali}$ & 8 & 13,3 \\
\hline & $>$ dari 1 kali & 10 & 16,7 \\
\hline \multirow{4}{*}{$\begin{array}{l}\text { Apa tepatnya gangguan tulang yang anda } \\
\text { alami? }\end{array}$} & Tidak ada & 42 & 70 \\
\hline & $\begin{array}{l}\text { Kepadatan } \\
\text { tulang rendah }\end{array}$ & 8 & 13,3 \\
\hline & Tulang retak & 7 & 11,7 \\
\hline & Patah tulang & 3 & 5 \\
\hline \multicolumn{2}{|l|}{ Total Partisipan } & 60 & 100 \\
\hline
\end{tabular}




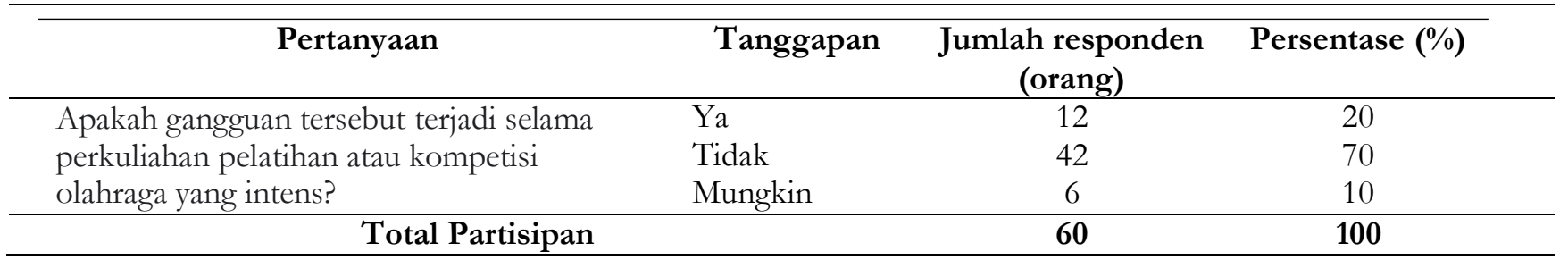

Hasil penelitian ini menyatakan sebanyak $71,7 \%(\mathrm{n}=45)$ responden pernah mengalami cedera, $6,6 \%$ $(\mathrm{n}=4)$ melaporkan lebih sering dan $21,7 \%(\mathrm{n}=13)$ responden melaporkan selama ini tidak pernah mengalami cedera. Responden yang melaporkan pernah mengalami gangguan tulang pada penelitian ini sebanyak $30 \%(\mathrm{n}=18)$ yaitu $13,3 \%(\mathrm{n}=8)$ responden mengalami gangguan kepadatan tulang yang rendah, $11,7 \%(n=7)$ responden mengalami retak pada tulang dan $5 \%$ (3 orang) responden pernah mengalami patah tulang. Sedangkan $70 \%(\mathrm{n}=42)$ dari responden melaporkan tidak pernah mengalami gangguan pada tulang.

Hasil penelitian ini menunjukkan beberapa dari responden pernah mengalami cedera, beberapa melaporkan lebih sering mengalami cedera berupa gangguan tulang seperti gangguan kepadatan tulang yang rendah, retak pada tulang dan patah tulang. Namun, mayoritas responden menyatakan kebiasaan tersebut tidak berkaitan dengan aktivitas yang dilakukan sehari-hari.

\section{Pengetahuan Sindroma FAT pada Mahasiswi Olahraga}

Tabel 6. Tanggapan Responden Tentang Pengetahuan Sindroma FAT

\begin{tabular}{|c|c|c|c|}
\hline Pertanyaan & Tanggapan & $\begin{array}{l}\text { Jumlah responden } \\
\text { (orang) }\end{array}$ & Persentase $(\%)$ \\
\hline Apakah anda pernah mendengar sindroma & $\mathrm{Ya}$ & 5 & 8,3 \\
\hline Female Atblete Triad sebelumnya? & Tidak & 55 & 91,7 \\
\hline Total Partisipan & & 60 & 100 \\
\hline \multirow{2}{*}{$\begin{array}{l}\text { Apakah anda pernah diberi tahu pelatih, } \\
\text { dosen, dokter atau orang lain terkait } \\
\text { sindroma tersebut? }\end{array}$} & $\mathrm{Ya}$ & 3 & 5 \\
\hline & Tidak & 57 & 95 \\
\hline Total Partisipan & & 60 & 100 \\
\hline
\end{tabular}

Hasil penelitian ini menunjukkan, 91,7\% (55 orang) responden dalam penelitian ini yang mewakili populasi mahasiswi olahraga tidak pernah mendengar tentang sindroma FAT sebelumnya. Hampir keseluruhan yaitu 95\% (57 orang) responden juga tidak mendapatkan pengetahuan dari orang lain termasuk pelatih, dosen dan dokter.

Hasil pengetahuan responden terkait sindroma FAT ini merupakan temuan yang mengejutkan. Hampir semua dari keseluruhan responden tidak pernah mendengar dan diberikan pengetahuan tentang sindroma FAT.

\section{Pembahasan}

\section{Aktivitas fisik dalam dan luar perkuliahan}

Aktivitas fisik, pelatihan dan kompetisi yang dilakukan secara rutin dan intens berdampak pada pengeluaran energi harian pada individu. pengeluaran energi yang melebihi konsumsi asupan kalori, mengarah pada kekurangan ketersediaan energi dan memengaruhi fungsi fisiologis tubuh. Konsekuensi gangguan kesehatan yang harus diterima adalah peningkatan risiko menderita sindroma FAT (Manore, Kam, \& Loucks, 2007). Risiko gangguan sindroma FAT dari frekuensi 
perkuliahan praktik lebih dari $5 \mathrm{kali} /$ minggu $11,7 \%(\mathrm{n}=7)$, frekuensi latihan diluar perkuliahan 5 kali/minggu atau lebih 30\% $(\mathrm{n}=18)$ dan responden menghabiskan kan waktu lebih dari 2 jam setiap latihan sebanyak 35\% ( $\mathrm{n}=21)$. Atlet dari berbagai cabang olahraga dan tingkatan kompetisi berpotensi mengalami FAT (Tosi et al., 2019). Olahraga menimbulkan stres metabolik (Pauli \& Berga, 2010) akibat beban latihan yang tidak mampu dikompensasi fisiologis tubuh, sehingga terjadi gangguan keseimbangan energi. Gangguan tersebut terjadi akibat dari perubahan respons fisiologis tubuh dalam rangka bertahan dari stres akibat pelatihan olahraga dan kekurangan ketersediaan energi karena peningkatan penggunaan energi untuk aktivitas latihan (House, Loud \& Shubkin, 2013; Warren \& Perlroth, 2001).

\section{Ketersediaan energi}

Aktivitas fisik yang tinggi meningkatkan pengeluaran energi yang tentunya harus diimbangi dengan asupan makanan yang memadai. Ketersediaan energi yang rendah dapat terjadi karena kegagalan mempertahankan nutrisi dan asupan kalori yang memadai selama pelatihan fisik ketat (Slater et al., 2017). Kekurangan ketersediaan energi biasanya disebabkan pembatasan makanan yang disengaja untuk menurunkan berat badan, diet rendah kalori untuk pengaturan badan khususnya pada cabor dengan tuntutan berat badan tertentu, atau tidak sengaja karena kurangnya nafsu makan pada periode pelatihan dengan volume yang tinggi (Burke et al., 2018).

Risiko gangguan ketersediaan energi dari riwayat frekuensi makan sebesar 50\% ( $\mathrm{n}=30)$, tuntutan pengaturan berat badan dari cabor $41,7 \%(n=25)$, pembatasan asupan kalori $25 \%(n=15)$, gaya hidup spesifik 40\% ( $n=24)$, kebiasaan puasa 60\% ( $n=36)$ dan gangguan nafsu makan $65 \%(n=39)$. Ketersediaan energi yang rendah dapat terjadi secara sengaja atau tidak sengaja dan tanpa gangguan makan, jika pengeluaran energi atlet melebihi asupan kalori yang dikonsumsi (Manore et al., 2007). Ketersediaan energi rendah juga dapat terjadi karena perilaku diet, gaya hidup spesifik seperti veganisme/vegetarian dan pembatasan jenis makanan tertentu (Slater et al., 2017).

\section{Menstruasi}

Perempuan dengan sindroma FAT dapat mengalami berbagai kelainan menstruasi termasuk amenorrbea, oligomenorrhea dan masalah dengan ovulasi (Ducher et al., 2011). Usia menarche rata-rata dari responden 75\% $(n=45)$ terjadi di usia 10-13 tahun dan 25\% $(n=15)$ di usia 14-16 tahun. Berdasarkan hasil penelitian ini, sebanyak $25 \%$ responden yang mengalami menarche di usia 14-16 tahun memiliki risiko besar telah mengalami amenorrbea primer. Menarche tertunda ( $>15$ tahun) berhubungan dengan kejadian fraktur stress pada atlet pelajar (Tenforde, Sayres, McCurdy, Sainani, \& Fredericson, 2013). Terkait dengan amenorrhea sekunder, sebanyak 53,3\% $(n=32)$ responden pernah kehilangan satu periode penuh dari siklus menstruasi biasanya. Sehingga gangguan amenorrhea pada mahasiswi olahraga baik primer maupun sekunder memiliki risiko yang besar untuk terjadi. Amenorrhea dapat muncul sebagai primer atau sekunder. Amenorrhea primer ditandai belum terjadinya menarche sampai usia 15 tahun, tetapi karakteristik seksual sekunder sudah muncul. Amenorrhea sekunder ditandai tidak adanya menstruasi lebih dari tiga siklus atau tiga bulan pada perempuan yang telah mengalami menstruasi teratur (Brown et al., 2017; Nattiv et al., 2007). Sebanyak 5\% $(n=3)$ responden juga melaporkan memiliki siklus menstruasi $>35$ hari dan 50\% $(n=30)$ responden pernah mengalami penundaan menstruasi selama lebih dari 35 hari, bahkan 6,7\% $(n=4)$ sering mengalami penundaan tersebut. Responden tersebut besar risikonya mengalami gangguan oligomenorrhea. Oligomenorrhea didefinisikan sebagai siklus haid yang terpisah lebih dari 35 hari (Nattiv et al., 2007). 


\section{Kepadatan tulang}

Risiko dari riwayat cedera 71,7\% $(\mathrm{n}=45), 6,6 \%(\mathrm{n}=4)$ responden lebih sering. Risiko dari riwayat gangguan kepadatan tulang sebanyak 30\% ( $\mathrm{n}=18)$ dengan rincian yaitu: $13,3 \% \quad(\mathrm{n}=8)$ riwayat gangguan kepadatan tulang yang rendah, $11,7 \%(n=7)$ riwayat retak pada tulang dan $5 \%(n=3)$ riwayat patah tulang. Cedera yang terjadi pada responden penelitian mungkin saja berkaitan dengan gangguan dari sindroma FAT. Hasil penelitian sebelumnya melaporkan, gangguan dari ketiga komponen FAT berhubungan dengan cedera muskuloskeletal pada atlet pelajar (Rauh, Nichols, \& Barrack, 2010). Konsekuensi dari sindroma FAT dalam jangka panjang adalah menurunkan kepadatan tulang, sehingga risiko cedera tulang meningkat (Gharib \& Ackerman, 2012). Cedera akan mengurangi efisiensi latihan, kinerja tim dan kemampuan kompetitif (Manore, Kam \& Loucks, 2007).

\section{Pengetahuan tentang sindroma FAT}

Risiko dari pengetahuan pribadi, sebanyak 91,7\% $(n=55)$ tidak memiliki pengetahuan pribadi dan $95 \% \quad(\mathrm{n}=57)$ tidak pernah mendapatkan informasi dari orang lain dilingkungannya yang berkompeten dalam bidangnya. Hal ini merupakan temuan yang mengejutkan dari penelitian ini, karena mahasiswi olahraga setelah menyelesaikan studinya akan menempati posisi-posisi yang berkaitan dengan pembinaan olahraga di seluruh Indonesia. Hal ini sejalan dengan temuan penelitian sebelumnya, bahwa kebanyakan atlet berisiko mengalami sindroma FAT, tetapi tidak banyak yang tahu tentang sindroma tersebut (Tosi et al., 2019). Pengetahuan tentang faktor risiko dan gejala sindroma FAT dari pelatih dan atlet, akan mengurangi risiko menderita sindroma FAT (K. N. Brown, Wengreen, \& Beals, 2014). Pengetahuan yang baik tentang sindroma FAT mendorong pendekatan yang komprehensif dalam diagnosa dan penanganan gangguan yang terjadi (Kroshus, DeFreese, \& Kerr, 2018). Tingkat pengetahuan tentang sindroma FAT pada pelatih dan atlet menjadi intervensi pencegahan yang terbaik terhadap kemungkinan terjadinya gangguan dimasa depan (Pantano, 2006).

\section{Simpulan dan Rekomendasi}

Gambaran dari hasil penelitian menunjukkan risiko mahasiswi olahraga menderita sindroma FAT cukup besar, dengan aktivitas fisik yang tinggi di luar maupun di dalam perkuliahan. Perlu dilakukan skrining dan pemeriksaan medis lanjutan terkait sindroma FAT kepada mahasiswi olahraga, seperti ovutest dan bone densitometri test untuk memastikan tidak mengalami gangguan dari sindroma FAT. Temuan yang paling mengejutkan dalam penelitian ini adalah rendahnya pengetahuan dan informasi terkait sindroma FAT di kalangan mahasiswi olahraga. Pencegahan dan penanganan gangguan sindroma FAT, akan menjadi sulit dengan rendahnya pengetahuan dan informasi yang dimiliki. Mengingat dampak yang besar terhadap kesehatan, perlu dilakukan edukasi terkait sindroma FAT kepada mahasiswi agar risiko terjadinya gangguan dapat dikurangi.

\section{Daftar Pustaka:}

Badriyah, S. (2019, July 31). Menko PMK Jadi Pembicara Kunci Seminar Women in Sport. Retrieved from https://www.kemenkopmk.go.id/artikel/menko-pmk-jadi-pembicara-kunci-seminar-womensport

Brown, K. A., Dewoolkar, A. V., Baker, N., \& Dodich, C. (2017). The female athlete triad: Special considerations for adolescent female athletes. Translational Pediatrics.

https://doi.org/10.21037/tp.2017.04.04 
Brown, K. N., Wengreen, H. J., \& Beals, K. A. (2014). Knowledge of the female athlete triad, and prevalence of triad risk factors among female high school athletes and their coaches. Journal of Pediatric and Adolescent Gynecology. https://doi.org/10.1016/j.jpag.2013.11.014

Burke, L. M., Lundy, B., Fahrenholtz, I. L., \& Melin, A. K. (2018). Pitfalls of conducting and interpreting estimates of energy availability in free-living athletes. International Journal of Sport Nutrition and Exercise Metabolism. https://doi.org/10.1123/ijsnem.2018-0142

De Souza, M. J., Toombs, R. J., Scheid, J. L., O’Donnell, E., West, S. L., \& Williams, N. I. (2010). High prevalence of subtle and severe menstrual disturbances in exercising women:

Confirmation using daily hormone measures. Human Reproduction. https://doi.org/10.1093/humrep/dep411

De Souza, Mary Jane, Nattiv, A., Joy, E., Misra, M., Williams, N. I., Mallinson, R. J., ... Matheson, G. (2014). 2014 female athlete triad coalition consensus statement on treatment and return to play of the female athlete triad: 1st international conference held in San Francisco, CA, May 2012, and 2nd international conference held in Indianapolis, IN, May 2013. Clinical Journal of Sport Medicine. https://doi.org/10.1097/JSM.0000000000000085

Ducher, G., Turner, A. I., Kukuljan, S., Pantano, K. J., Carlson, J. L., Williams, N. I., \& De Souza, M. J. (2011). Obstacles in the optimization of bone health outcomes in the female athlete triad. Sports Medicine. https://doi.org/10.2165/11588770-000000000-00000

Gharib, T., \& Ackerman, K. (2012). (Athletic Training) Female Athlete Triad. Sports Health, 4(4), 302-311. https://doi.org/10.1177/1941738112439685

Hoch, A. Z., Pajewski, N. M., Moraski, L., Carrera, G. F., Wilson, C. R., Hoffmann, R. G., ... Gutterman, D. D. (2009). Prevalence of the female athlete Triad in high school athletes and sedentary students. Clinical Journal of Sport Medicine.

https://doi.org/10.1097/JSM.0b013e3181b8c136

House, S., Loud, K., \& Shubkin, C. (2013). Female athlete triad for the primary care pediatrician. Current Opinion in Pediatrics. https://doi.org/10.1097/MOP.0000000000000033

KEMENPORA RI. (2012, June 26). Kita Bisa Rebut Emas Olimpiade! Retrieved from http://kemenpora.go.id/index/preview/berita/6008

KEMENPORA RI. (2016a). Menpora: Medali Perak Sri Wabyuni Harus Jadi Motivasi Atlet Indonesia yang Lain. Retrieved from http://www.kemenpora.go.id/index/preview/berita/10802

KEMENPORA RI. (2016b, June 26). Siaran Pers No. 23/Kom-Publik/Kemenpora/ 6:2016: Pemberian Bonus Bagi Atlet Asean Para Games dan Jaminan Hari Tua Bagi Peraih Medali Olimpiade. Retrieved from http://kemenpora.go.id/index/preview/pers/216

KEMENPORA RI. (2018, August 19). Menpora Harap Emas Pertama Defia Bisa Menular ke Atlet Indonesia yang Lain. Retrieved from http://www.kemenpora.go.id/index/preview/berita/12718

Kroshus, E., DeFreese, J. D., \& Kerr, Z. Y. (2018). Collegiate athletic trainers' knowledge of the female athlete triad and relative energy deficiency in sport. Journal of Atbletic Training. https://doi.org/10.4085/1062-6050-52.11.29

Manore, M. M., Kam, L. C., \& Loucks, A. B. (2007). The female athlete triad: components, nutrition issues, and health consequences... 2007 IAAF Consensus Conference on Nutrition for 
Athletics. Journal of Sports Sciences.

Matzkin, E., Curry, E. J., \& Whitlock, K. (2015). Female Athlete Triad: Past, Present, and Future. Journal of the American Academy of Orthopaedic Surgeons. https://doi.org/10.5435/JAAOS-D-1400168

Nattiv, A, Agostini, R., Drinkwater, B., \& Yeager, K. K. (1994). The female athlete triad. The interrelatedness of disordered eating, amenorrhea, and osteoporosis. Clinics in Sports Medicine. https://doi.org/10.1080/00098650209603960

Nattiv, Aurelia, Loucks, A. B., Manore, M. M., Sanborn, C. F., Sundgot-Borgen, J., \& Warren, M. P. (2007). American College of Sports Medicine position stand. The Female Athlete Triad. Medicine \& Science in Sports \& Exercise. https://doi.org/10.1249/mss.0b013e318149f111

Pantano, K. J. (2006). Current knowledge, perceptions, and interventions used by collegiate coaches in the u.s. Regarding the prevention and treatment of the female athlete triad. North American Journal of Sports Physical Therapy: NAJSPT, 1(4), 195-207.

Pauli, S. A., \& Berga, S. L. (2010). Athletic amenorrhea: Energy deficit or psychogenic challenge. Annals of the New York Academy of Sciences. https://doi.org/10.1111/j.1749-6632.2010.05663.x

Rauh, M. J., Nichols, J. F., \& Barrack, M. T. (2010). Relationships among injury and disordered eating, menstrual dysfunction, and low bone mineral density in high school athletes: A prospective study. Journal of Athletic Training. https://doi.org/10.4085/1062-6050-45.3.243

Sherwood, L. (2016). Human physiology from cells to systems Ninth Edition. Appetite. https://doi.org/10.1016/j.appet.2008.10.006

Slater, J., Brown, R., McLay-Cooke, R., \& Black, K. (2017). Low Energy Availability in Exercising Women: Historical Perspectives and Future Directions. Sports Medicine. https://doi.org/10.1007/s40279-016-0583-0

Tenforde, A. S., Sayres, L. C., McCurdy, M. L., Sainani, K. L., \& Fredericson, M. (2013). Identifying sex-specific risk factors for stress fractures in adolescent runners. Medicine and Science in Sports and Exercise. https://doi.org/10.1249/MSS.0b013e3182963d75

Tosi, M., Maslyanskaya, S., Dodson, N. A., \& Coupey, S. M. (2019). The Female Athlete Triad: A Comparison of Knowledge and Risk in Adolescent and Young Adult Figure Skaters, Dancers, and Runners. Journal of Pediatric and Adolescent Gynecology. https://doi.org/10.1016/j.jpag.2018.10.007

Warren, M. P., \& Perlroth, N. E. (2001). The effects of intense exercise on the female reproductive system. Journal of Endocrinology. https://doi.org/10.1677/joe.0.1700003 